\title{
Disiplin Verifikasi Wartawan Tribunnews.com dan Detik.com dalam Pemberitaan Penganiayaan Ratna Sarumpaet
}

\author{
Muhammad Fajar Rivaldi, Dadang Rahmat Hidayat, dan Dandi Supriadi \\ Fakultas Ilmu Komunikasi, Universitas Padjadjaran \\ rivaldifajar24@gmail.com
}

\begin{abstract}
This research examines verification process of Tribunnews.com and Detik.com journalists in reporting Ratna Sarumpaet's alleged persecution case. Both media claimed the persecution is true by only relying to information from posts in her political affiliations' social media accounts. This study aims to determine the implementation of discipline of verification by the two media outlets, how they treated information resources, and how far the responsibility of Tribunnews.com and Detik.com has reached the reliability of information from social media. The inquiry seeks answers by using the Robert K. Yin's case study method. Results show, the verification process conducted just at the phase of checking the authenticity of social media accounts. Whereas the thruth of the information was not verified yet. In treating sources from social media, both media outlets would trust verified accounts. While Tribunnews.com has formed a social media team, Detik.com still relies on the confirmation of the authorities to account for information from social media. In conclusion, regarding the hoax case of Ratna Sarumpaet, Tribunnews.com and Detik.com have not carried out the discipline of verification perfectly on some of the initial news. There were six news in Tribunnews. com and three in Detik.com that seemed to be confirming the incidents of the unrevealed persecution of Ratna. There was verification endeavor after that, but it was too shallow, which means they did not explicitly verify the truth about this information.
\end{abstract}

Keywords: case study; Detik.com; Ratna Sarumpaet; discipline of verification; Tribunnews.com

\begin{abstract}
Abstrak
Penelitian ini mengkaji proses verifikasi wartawan Tribunnews.com dan Detik.com dalam memberitakan kasus dugaan penganiayaan Ratna Sarumpaet. Kedua media mengklaim penganiayaan itu benar dengan hanya mengandalkan informasi dari postingan di akun media sosial afiliasi politiknya. Penelitian ini bertujuan untuk mengetahui penerapan disiplin verifikasi oleh kedua media tersebut, bagaimana mereka memperlakukan sumber informasi, dan sejauh mana tanggung jawab Tribunnews.com dan Detik.com mencapai keandalan informasi dari media sosial. Pencarian jawaban dilakukan dengan menggunakan metode studi kasus Robert K. Yin. Hasil menunjukkan, proses verifikasi yang dilakukan baru pada tahap pengecekan keaslian akun media sosial. Sementara kebenaran informasi itu belum diverifikasi. Dalam memperlakukan sumber dari media sosial, kedua media akan mempercayai akun yang diverifikasi. Di saat Tribunnews. com telah membentuk tim media sosial, Detik.com masih menggunakan konfirmasi pihak berwenang untuk mempertanggungjawabkan informasi dari media sosial. Kesimpulannya, terkait kasus hoaks Ratna Sarumpaet, Tribunnews.com dan Detik.com belum melakukan disiplin verifikasi secara sempurna pada beberapa berita awal. Ada enam berita di Tribunnews.com dan tiga di Detik.com yang seolah membenarkan insiden penganiayaan terhadap Ratna yang belum terungkap. Ada upaya verifikasi setelah itu, tapi itu terlalu dangkal, artinya mereka tidak secara eksplisit memverifikasi kebenaran informasi tersebut.
\end{abstract}

Kata Kunci: Detik.com; disiplin verifikasi; Ratna Sarumpaet; studi kasus; Tribunnews. com

Korespondensi: Muhammad Fajar Rivaldi, S.I.Kom., Fakultas Ilmu Komunikasi Universitas Padjadjaran, Jl. Raya Bandung Sumedang KM. 21, Kec. Jatinangor, Kabupaten Sumedang, Jawa Barat, 45363, Email: rivaldifajar24@gmail.com

Menyerahkan: Januari 2021, Diterima: Desember 2021, Terbit: Januari 2022

ISSN: 2549-0559 (cetak), ISSN: 2549-1946 (online), Website: http://jurnal.unpad.ac.id/kajian-jurnalisme 
Volume 05 Nomor 02 Tahun 2022

DOI: $10.24198 /$ jkj.v5i2.31701

\section{PENDAHULUAN}

Aktris sekaligus aktivis hak asasi manusia (HAM), Ratna Sarumpaet, membuat heboh masyarakat Indonesia pada 2 Oktober 2018, usai beredarnya foto-foto yang memperlihatkan wajah lebamnya pada akun media sosial Facebook atas nama Swary Utami yang menyertakan komentar bernada pembelaan untuk Ratna yang diklaim mengalami penganiayaan. Kabar ini kemudian dikonfirmasi oleh rekan-rekan politiknya dan mereka menyebut bahwa Ratna dipukuli oleh tiga orang tak dikenal di Bandara Husein Sastranegara Bandung pada 21 September 2018. Pihak kepolisian kota Bandung kemudian menindaklanjuti kasus tersebut tapi mereka mendapat fakta yang berseberangan, yaitu bahwa Ratna Sarumpaet tidak mengalami tindakan penganiayaan melainkan melakukan operasi plastik di Rumah Sakit Bedah Bina Estetika di kawasan Menteng, Jakarta Pusat. Temuan fakta dari kepolisian itu akhirnya membuat Ratna mengaku peristiwa penganiayaan tersebut tidak benar, ia hanya sekadar berbohong kepada keluarganya (Khotimah \& Nuraeni, 2019).

Walaupun kasus dugaan penganiayaan Ratna Sarumpaet baru terbukti pada Rabu 3 Oktober 2018 pada sore hari, nyatanya ada beberapa media massa, khususnya media massa daring, yang mengabarkan pemukulan terhadap Ratna Sarumpaet adalah benar. Berdasarkan hasil observasi peneliti, Tribunnews.com menjadi salah satu media massa online yang banyak memberitakan tentang kasus hoaks Ratna Sarumpaet dengan total 124 berita. Enam di antaranya menggunakan konten media sosial sebagai kutipan narasumber dalam berita, tanpa menggunakan kata 'dikabarkan' atau 'diduga' pada judul beritanya. Media massa daring lainnya yang rajin memberitakan kasus hoaks Ratna Sarumpaet adalah Detik.com yang membuat total 13 berita dengan tiga berita yang minim verifikasi dan menggunakan media sosial sebagai kutipan narasumber dan tidak menggunakan kata 'diduga'/'dikabarkan' pada judul beritanya.

Dari berbagai berita media daring yang turut memberitakan tentang Ratna Sarumpaet, timbul keraguan tentang disiplin verifikasi wartawan Tribunnews.com dan Detik.com karena beberapa alasan. Pertama, Tribunnews.com dan Detik.com membuat berita yang belum pasti kebenarannya tanpa menggunakan kata 'dikabarkan' atau 'diduga' pada judul berita. Kesan yang muncul justru menghakimi bahwa pemukulan yang dialami oleh Ratna Sarumpaet benar adanya. Berita-berita itu juga berdampak pada khalayak yang percaya bahwa kejadian itu benar karena membaca berita tersebut hingga mereka turut mengutuk tindakan keji tersebut.

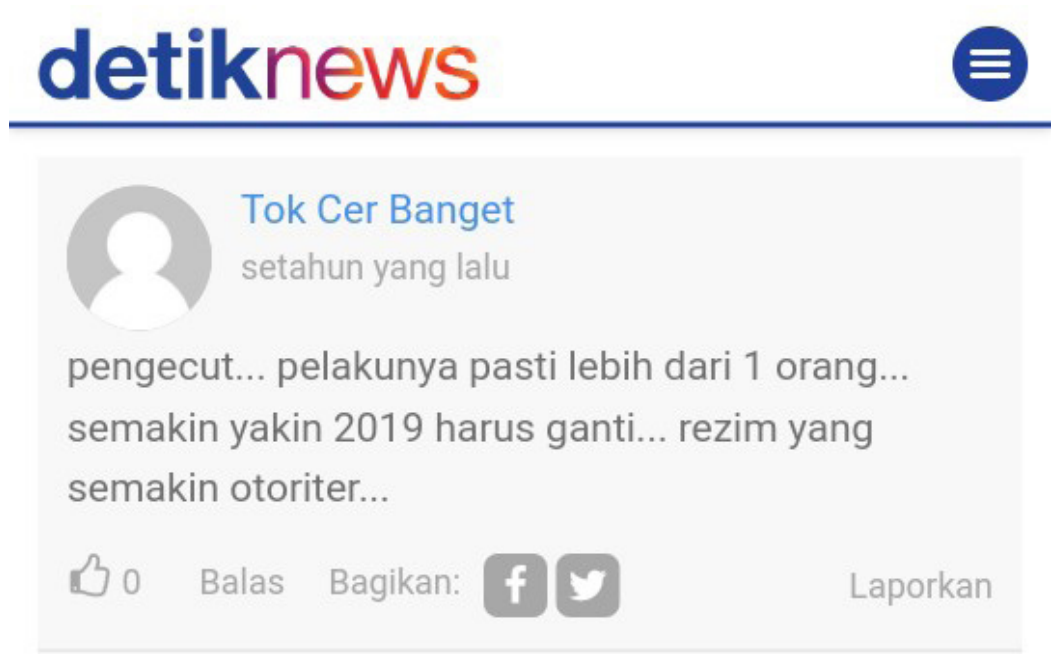

Gambar 1. Komentar Pembaca Detik.com tentang penganiayaan Ratna Sumber: Berita Detik.com berjudul "Fadli Zon Jenguk Ratna Sarumpaet yang Dianiaya, Begini Kondisinya" 
162 | Kajian Jurnalisme

Volume 05 Nomor 02 Tahun 2022

DOI: $10.24198 / \mathrm{jkj} . v 5 \mathrm{i} 2.31701$

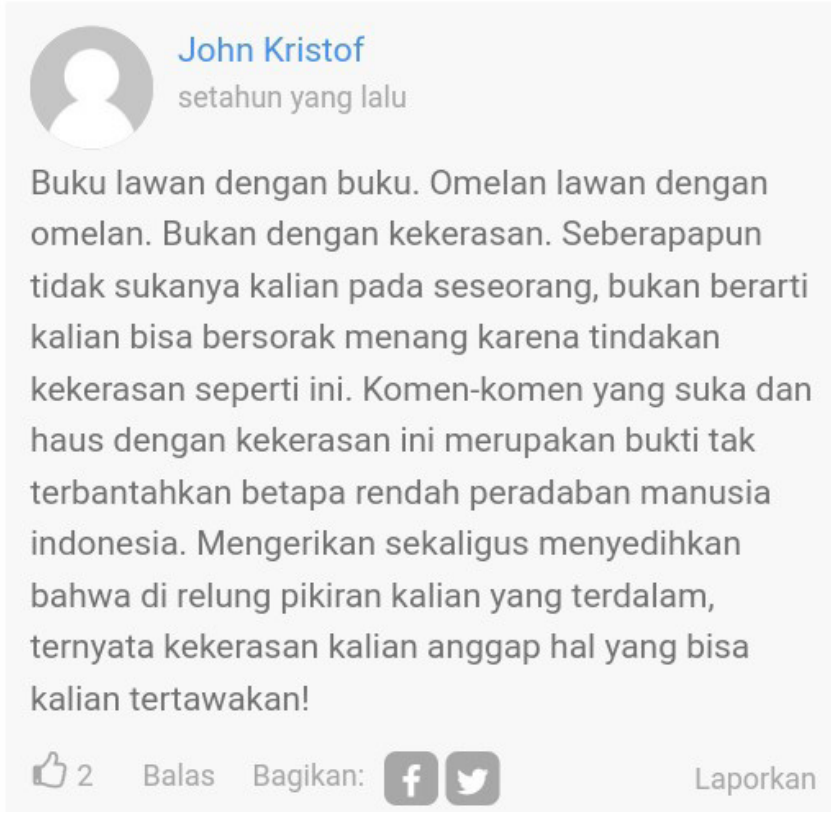

Gambar 2. Komentar Pembaca Detik.com tentang penganiayaan Ratna

Sumber: Berita Detik.com berjudul "Prabowo Temui Ratna Sarumpaet, Simak Cerita Penganiayaan"

Kedua, mayoritas berita di Tribunnews.com dan Detik.com hanya melakukan klarifikasi pada rekan-rekan politik Ratna saja. Bahkan pernyataan dari rekan-rekan politik tersebut mayoritas diambil dari postingan media sosial narasumber. Kedua media tersebut tidak melakukan verifikasi ke pihak bandara sebagai tempat yang dikabarkan menjadi TKP, atau kepolisian yang menangani kasus tersebut dalam satu berita yang sama.

Kedua hal di atas menjadi penting mengingat Tribunnews.com dan Detik.com merupakan dua situs berita yang cukup banyak dikonsumsi oleh khalayak atau pembaca media daring di Indonesia. Hal tersebut terlihat pada situs peringkat website dunia Alexa.com, di mana Tribunnews.com dan Detik.com menempati posisi tiga besar, yaitu Tribunnews.com posisi kedua dan Detik.com berada di peringkat ketiga sebagai situs berita paling populer di Indonesia, hingga Februari 2020.

Lebih jauh lagi, ternyata baik Tribunnews.com dan Detik.com terlihat sudah biasa memuat kutipan narasumber dalam berita dengan bersumber dari akun media sosial. Ini dapat dilihat dari beberapa berita yang didapatkan peneliti, contohnya pada berita di media online Tribunnews Manado.com, yang berjudul Fadli Zon Pertanyakan Nawacita Presiden Jokowi Saat Menjadi Capres Tahun 2014 (Umar, 2019). Pada berita tersebut, semua kutipan diambil dari Twitter pribadi Fadli Zon@fadlizon, tanpa ada satu pun kutipan berupa wawancara langsung. Sementara Detik.com pun kerap menggunakan cara yang sama dalam membuat berita. Pada berita berjudul Ahmad Dhani Ditahan, Fahri Hamzah: Elektabilitas Jokowi Bakal Turun, Detik.com mengambil kutipan wawancara dari Fahri Hamzah dari akun Twitternya (Batubara, 2019).

Dari kasus dugaan penganiayaan terhadap Ratna Sarumpaet yang dijelaskan di atas, juga dengan adanya media massa yang membenarkan kabar atau tidak melakukan verifikasi secara tegas karena hanya memberikan dugaan dalam beritanya, muncul pertanyaan bagi peneliti: Bagaimana disiplin verifikasi yang dilakukan wartawan media daring Tribunnews. com dan Detik.com dalam memberitakan kasus Ratna Sarumpaet? Hal ini menjadi penting dijawab, terutama setelah kemudian terungkap bahwa Ratna Sarumpaet berbohong tentang penganiayaan yang dialaminya. 
Masih sedikit ditemukan studi tentang disiplin verifikasi wartawan seperti ini. Dalam penelitian-penelitian terdahulu, jarang ada yang benar-benar fokus pada penerapan disiplin verifikasi wartawan terkait pemberitaan yang informasinya bersumber dari media sosial. Salah satu studi yang berbicara tentang hal tersebut terdapat pada artikel ilmiah berjudul "Emerging journalistic verification practices concerning social media" (Brandtzaeg, Lüders, Spangenberg, Rath-Wiggins, \& Følstad, 2015). Ini merupakan salah satu studi awal tentang verifikasi informasi yang bersumber pada media sosial, diterbitkan dalam jurnal Journalism Practice edisi bulan Maret 2015. Dalam studi kualitatif yang mengambil data dari 24 orang jurnalis daring pada saat itu, baru ditemukan beberapa strategi verifikasi informasi serta gagasan untuk menggunakan aplikasi khusus untuk melakukannya. Artikel tersebut hanya berbicara tentang gagasan ideal bagaimana melakukan verifikasi terhadap konten media sosial, belum mengomentari kasus tertentu yang dijadikan objek penelitian tentang implementasi disiplin verifikasi wartawan.

Artikel ilmiah lain yang berbicara tentang penggunaan sumber dari media sosial diterbitkan jurnal Journalism dengan judul "Trust in distant sources: An analytical model capturing antecedents of risk and trustworthiness as perceived by journalists" (Wintterlin, 2020). Artikel ini lebih berbicara tentang proses bagaimana membangun hubungan kepercayaan antara jurnalis dengan pemilik akun media sosial, yang didapat dari hasil wawancara dengan 12 orang jurnalis Jerman. Dari hasil studi ini didapat sebuah model analisis berdasarkan kajian sosiologis dan psikologis yang dapat digunakan untuk membangun kepercayaan antara jurnalis dan sumbernya, terutama di daerah krisis.

Kedua artikel di atas telah mengangkat masalah kebenaran informasi sebagai hal yang penting saat mengambil data dari media sosial. Namun keduanya belum berbicara dengan mendalam tentang kasus yang berhubungan dengan penerapan disiplin verifikasi di dalam proses jurnalistik.

Di Indonesia, penelitian yang berhubungan dengan penerapan disiplin verifikasi terhadap informasi media sosial belum banyak ditemukan. Kebanyakan studi yang ada lebih membahas tentang penggunaan media sosial sebagai alat distribusi dan pencarian informasi, serta bagaimana konten media sosial digunakan untuk memperkuat konstruksi politis yang dibuat oleh agenda media itu sendiri. Salah satunya terdapat pada artikel ilmiah berjudul "Penggunaan Twitter Sebagai Medium Distribusi Berita dan Newsgathering oleh Tirto.id" (Paramastri \& Gumilar, 2019). Artikel ini hanya membahas bagaimana penggunaan media sosial twitter oleh media daring dalam menyebarkan berita sekaligus tempat mengumpulkan informasi.

Sehubungan dengan agenda media, penulis menemukan salah satu penelitian berjudul "Media Agenda on Yogyakarta Sultanate Succession" (Nasionalita \& Nugroho, 2020). Walaupun tidak secara khusus berbicara tentang jurnalisme daring, namun artikel ini menunjukkan bahwa media massa memiliki agenda tersendiri dalam mengangkat sebuah isu. Sebuah kejadian yang sama dapat menjadi berita yang berbeda-beda penekanannya dalam media yang berbeda.

Berkaitan dengan kasus Ratna Sarumpaet, terdapat sebuah artikel ilmiah yang berbicara hal yang sama namun dengan kajian yang berbeda. Artikel berjudul "Konstruksi Media Pada Politikus Wanita: Judul Pemberitaan Kasus Hoaks Tokoh Politik Perempuan di Media Massa Online Indonesia" (Triadi \& Aziz, 2019) mengambil kasus hoaks Ratna Sarumpaet sebagai subjek penelitian. Namun studi ini hanya membahas tentang bagaimana media massa daring memilih perspektif pemberitaan secara tekstual berdasarkan sumber-sumber media sosial, melalui analisis kritis terhadap judul yang mereka gunakan. Tidak ada pembahasan tentang bagaimana wartawan media massa yang bersangkutan memverifikasi informasi yang mereka dapatkan dari media sosial.

Masalah verifikasi itu sendiri sebenarnya merupakan hal penting bagi seorang jurnalis 
164 | Kajian Jurnalisme

Volume 05 Nomor 02 Tahun 2022

DOI: $10.24198 / \mathrm{jkj} . v 5 \mathrm{i} 2.31701$

dalam setiap pembuatan berita. Bahkan Bill Kovach dan Tom Rosenstiel mengatakan bahwa intisari jurnalisme adalah disiplin verifikasi. Pada akhirnya, disiplin verifikasi adalah ihwal yang memisahkan jurnalisme dan hiburan, propaganda, fiksi, atau seni. Kovach dan Rosenstiel menawarkan lima konsep lain dalam melakukan produksi berita yang terverifikasi kebenarannya, yaitu: 1) Jangan menambah atau mengarang apa pun; 2) Jangan menipu atau menyesatkan pembaca, pemirsa, maupun pendengar; 3) Bersikaplah setransparan dan sejujur mungkin tentang metode dan motivasi Anda dalam melakukan reportase; 4) Bersandarlah terutama pada reportase Anda sendiri; dan 5) Bersikaplah rendah hati (Kovach \& Rosenstiel, 2014).

Di Indonesia, pentingnya verifikasi juga sudah diatur dalam Kode Etik Jurnalistik (KEJ), yaitu pada pasal 3 yang berbunyi: "Wartawan Indonesia selalu menguji informasi, memberitakan secara berimbang, tidak mencampurkan fakta dan opini yang menghakimi, serta menerapkan asas praduga tak bersalah" (Winora, Hidayat Rahmat, \& Besman, 2021). Juga dapat dilihat pada Pedoman Pemberitaan Media Siber (PPMS) butir kedua, yaitu verifikasi dan keberimbangan berita, yang mana terdapat tiga poin penjelasan verifikasi. Pertama, pada prinsipnya setiap berita harus melalui proses verifikasi. Kedua, berita yang dapat merugikan pihak lain memerlukan verifikasi pada berita yang sama untuk memenuhi prinsip akurasi dan keberimbangan. Sementara untuk yang ketiga, ketentuan berita harus melalui verifikasi dapat dikecualikan, dengan lima ketentuan, yakni: berita benar-benar mengandung kepentingan publik yang bersifat mendesak; sumber berita adalah keterangan dari lembaga resmi dengan mencantumkan identitas sumber secara jelas; subjek berita tidak diketahui keberadaannya dan atau tidak mungkin diwawancarai (Khalid, 2019).

PPMS merupakan fondasi etika wartawan media daring, mengingat media daring memiliki karakteristik khusus. Karakteristik khusus jurnalistik daring yang membedakannya dengan media konvensional salah satunya adalah immediacy, yaitu kesegaran atau kecepatan penyampaian informasi (Nur \& Wardiana, 2018). Selain itu, ada pula karakteristik multiple pagination, yang memungkinkan ratusan halaman dapat terkait satu sama lain dan juga bisa dibuka secara mandiri. Karakteristik lainnya adalah multimedia, yang memberikan kapabilitas untuk menyajikan gabungan teks, gambar, audio, video, dan grafis sekaligus. Lalu karakteristik archeiving, di mana data dan informasi dapat terarsipkan, dikelompokkan berdasarkan rubrik/ kategori atau kata kunci, juga tersimpan dan bisa diakses kapan saja. Terakhir, relationship with reader, yaitu kontak atau interaksi dengan pembaca yang dapat berlangsung simultan melalui kolom komentar (Juditha, 2013).

Dari penjelasan di atas, dapat dipastikan bahwa studi ini memiliki originalitas tinggi karena belum ada penelitian serupa tentang disiplin verifikasi wartawan, terutama dalam kasus hoaks peganiayaan Ratna Sarumpaet. Selain itu, pembahasan tentang disiplin verifikasi dalam dunia jurnalistik merupakan hal yang penting dan utama untuk menjaga kualitas pekerjaan jurnalistik itu sendiri.

Khususnya dalam studi ini, selain untuk mengetahui penerapan disiplin verifikasi wartawan Tribunnews.com dan Detik.com, peneliti juga bermaksud mencari tahu seperti apa perlakuan Tribunnews.com dan Detik.com terhadap sumber informasi, serta bagaimana Tribunnews.com dan Detik.com mempertanggungjawabkan reliabilitas informasi dari media sosial, dengan merujuk kepada konsep-konsep jurnalistik dan regulasi yang berlaku.

\section{METODE}

Dalam penelitian ini penulis menggunakan paradigma penelitian kualitatif. Penelitian kualitatif didefinisikan sebagai studi tentang fenomena alam, termasuk kualitasnya, perbedaan 
implementasi, konteks di mana fenomena muncul atau perspektif dari fenomena itu, tapi tidak termasuk jangkauan, frekuensi, dan tempat fenomena dalam suatu objek rantai sebab akibat yang ditentukan secara khusus (Loraine, Wick, \& Gumbinger, 2020). Penelitian kualitatif menekankan sifat realita yang terbangun secara sosial, hubungan erat antara peneliti dengan subjek yang diteliti dan penekanan pada makna situasi penyelidikan (Hidayat \& Anisti, 2015).

Studi ini menggunakan metode studi kasus Robert K. Yin untuk mengetahui bagaimana disiplin verifikasi yang dilakukan oleh wartawan Tribunnews.com dan Detik.com dalam memberitakan hoaks Ratna Sarumpaet. Dari situ kemudian dapat diketahui bagaimana mediamedia daring tersebut memperlakukan sumber informasi utama serta bagaimana mereka mempertanggungjawabkan reliabilitas informasi yang berasal dari media sosial.

Secara umum, studi kasus merupakan strategi yang lebih cocok bila pokok pertanyaan suatu penelitian berkenaan dengan how dan why. Yin menjabarkan lima langkah dalam melakukan studi kasus, yaitu: 1) menentukan dan menjabarkan pertanyaan penelitian; 2) memilih dan menentukan disain dan instrumen penelitian; 3) menentukan teknik pengumpulan data dan melakukan kegiatan pengumpulan data; 4) membuat analisa data; dan 5) mempersiapkan laporan akhir penelitian (Yin, 2014).

Dalam studi ini, setelah menentukan pertanyaan penelitian seperti yang telah disebutkan sebelumnya, peneliti menggunakan instrumen berupa hasil wawancara terhadap redaksi dan wartawan kedua media untuk mengetahui penerapan disiplin verifikasi mereka. Peneliti juga menelusuri pendapat anggota Dewan Pers untuk memverfifikasi data dan fakta yang didapat sekaligus memperloeh informasi tambahan yang memperkuat hasil penelitian. Instrumen lainnya adalah berita-berita di Tribunnews.com dan Detik.com yang membenarkan pemukulan terhadap Ratna Sarumpaet dan mengambil pernyataan narasumber dari media sosial. Juga dilihat beberapa bukti tangkapan layar (screenshot) kolom komentar dari berita-berita yang membenarkan insiden tersebut.

Setelah itu penulis menganalisis berita-berita tersebut dengan menggunakan konsepkonsep verifikasi dari Brandtzaeg et al. (2015), Kovach dan Rosenstiel (2014), serta prinsip KEJ dan PPMS dari Dewan Pers.

\section{HASIL DAN PEMBAHASAN}

Instrumen pertama dalam studi kasus ini diambil dari hasil wawancara dengan redaksi Tribunnews.com dan Detik.com yang mengetahui proses pembuatan berita masalah dugaan penganiayaan Ratna Sarumpaet. Mereka adalah Yulis Sulistiawan (News Manager Tribunnews. com), Widie Henaldi (Editor Tribunnews.bogor.com), Fajar Pratama (Redaktur Pelaksana Detiknews), Danu Damarjati (Reporter Detiknews), serta pihak Dewan Pers untuk mendapatkan pendapat profesional di luar media yang bersangkutan, yaitu Ahmad Djauhar (Wakil Ketua Dewan Pers).

Untuk instrumen berikutnya, peneliti mengambil enam berita dari Tribunnews.com dan tiga berita dari Detik.com untuk diobservasi. Berita-berita yang dipilih adalah berita pertama yang muncul di tanggal 2 Oktober 2018, yang membenarkan kasus Ratna Sarumpaet dan menggunakan postingan media sosial Twitter sebagai kutipan narasumber. Judul berita-berita terpilih tersebut dapat dilihat pada Tabel 1 dan 2 . 
166 | Kajian Jurnalisme

Volume 05 Nomor 02 Tahun 2022

DOI: $10.24198 / \mathrm{jkj} . v 5 \mathrm{i} 2.31701$

Tabel 1. Kumpulan berita awal mengenai Ratna Sarumpaet di Tribunnews.com

\begin{tabular}{|c|c|l|}
\hline Hari dan Tanggal & Waktu & \multicolumn{1}{|c|}{ Judul Berita } \\
\hline Selasa, 2 Oktober 2018 & $12: 25$ WIB & $\begin{array}{l}\text { Ratna Sarumpaet Babak Belur Dipukuli Orang Tak Dikenal, } \\
\text { Ferdinand Hutahean: Gila Edan! }\end{array}$ \\
\hline Selasa, 2 Oktober 2018 & $12: 54$ WIB & $\begin{array}{l}\text { Ratna Sarumpaet Dianiaya Hingga Babak Belur Rizal } \\
\text { Ramli: Penghinaan Demokrasi Beraninya Sama Ibu-ibu }\end{array}$ \\
\hline Selasa, 2 Oktober 2018 & $12: 54$ WIB & $\begin{array}{l}\text { Ratna Sarumpaet Dipukuli Hingga Babak Belur Fahira } \\
\text { Idris: Stop Kekerasan Terhadap Aktivis Perempuan }\end{array}$ \\
\hline Selasa, 2 Oktober 2018 & $16: 35$ WIB & $\begin{array}{l}\text { Ratna Sarumpaet Dipukuli Kariernya Bermula dari } \\
\text { Sutradara Drama Hingga Kini Jadi Juru Kampanye }\end{array}$ \\
\hline Selasa, 2 Oktober 2018 & $17: 55$ WIB & $\begin{array}{l}\text { Ratna Sarumpaet Dikeroyok, Fadli Zon Kabarkan Kondisi } \\
\text { Terbarunya }\end{array}$ \\
\hline Selasa, 2 Oktober 2018 & $17: 56$ WIB & $\begin{array}{l}\text { Ratna Sarumpaet Jadi Korban Pemukulan, IG Rio Dewanto } \\
\text { Banjir Pertanyaan Seputar Kondisi sang Mertua }\end{array}$ \\
\hline
\end{tabular}

Sumber: Hasil Temuan Peneliti dari Tribunnews.com

Tabel 2. Kumpulan berita awal mengenai Ratna Sarumpaet di Detik.com

\begin{tabular}{|c|c|l|}
\hline Hari dan Tanggal & Waktu & \multicolumn{1}{|c|}{ Judul Berita } \\
\hline Selasa, 2 Oktober 2018 & $13: 24$ WIB & $\begin{array}{l}\text { Fadli Zon Jenguk Ratna Sarumapet yang Dianiaya } \\
\text { Begini Kondisinya }\end{array}$ \\
\hline Selasa, 2 Oktober 2018 & $18: 10$ WIB & $\begin{array}{l}\text { Prabowo Temui Ratna Sarumpaet Simak Cerita } \\
\text { Penganiayaan }\end{array}$ \\
\hline Selasa, 2 Oktober 2018 & $12: 54$ WIB & $\begin{array}{l}\text { Begini Cerita Penganiayaan Ratna Sarumpaetyang } \\
\text { Disampaikan ke Prabowo }\end{array}$ \\
\hline
\end{tabular}

Sumber: Hasil Temuan Peneliti dari Detik.com

Berdasarkan hasil analisis menggunakan studi kasus, baik Tribunnews.com maupun Detik.com sama-sama memandang penting kasus Ratna Sarumpaet, sehingga mereka cepat membuat berita tersebut meski kasus masih berupa dugaan, atau membenarkan berita tersebut karena merasa telah mendapat informasi dari orang-orang terdekat Ratna meski hanya didapat melalui akun media sosial mereka. Yulis Sulistiawan, Manajer Pemberitaan dan Manajer Konten Tribunnews.com mengatakan, kasus ini penting untuk diberitakan karena terkait dengan situasi 'panas' tahun politik 2018 pada pemilihan presiden atau pilpres, di mana Ratna yang diduga korban berada di kubu yang berseberangan dengan capres petahana Joko Widodo. Selain itu, Ratna adalah seorang figur publik perempuan yang dikenal vokal mengkritik pemerintah (Sulistiawan, Wawancara. 21 Agustus 2019).

Sementara Detik.com memberitakan kasus ini karena peristiwa tersebut 'ada secara jurnalistik', yaitu bahwa peristiwa terebut secara jurnalistik ada karena terdapat kabar yang mengatakan Ratna Sarumpaet dipukuli yang disampaikan oleh orang-orang terdekat Ratna (Pratama, Wawancara. 26 Oktober 2019). Orang-orang terdekat yang dimaksud adalah anggota tim badan pemenangan Prabowo - Sandi di Pilpres 2019 yang dinilai redaksi kredibel untuk menyatakan kondisi Ratna Sarumpaet.

Kedua media tersebut juga mengaku tetap melakukan verifikasi dari pemberitaan yang mereka dapat dari media sosial, namun tetap memilih terlebih dahulu merilis berita dengan kutipan media sosial untuk mengejar kecepatan dan urgensi publik. Upaya verifikasi Tribunnews.com dilakukan setelah pertama kali mendapat kabar pemukulan Ratna Sarumpaet dari viralnya foto Ratna babak belur yang beredar di media sosial. 
Kita belum sampai pada posisi bahwa Ratna Sarumpaet dikeroyok atau apapun, kita hanya tahu Ratna Sarumpaet babak belur. Insting jurnalis kita berpikir bahwa ada apa ya? Apa bener ya seorang Ratna Sarumpaet babak belur? Logika berpikir kita pasti ada sesuatu yang terjadi pada Ratna Sarumpaet saat itu, tapi kita belum bisa mengangkat bahwa itu Ratna Sarumpaet dipukuli siapa segala macam. (Henaldi, Wawancara. 21 Agustus 2019).

Setelah mendapat kabar tersebut redaksi langsung menghubungi Ratna, namun mereka tidak mendapat jawaban. Tim Tribunnews.com pun beralih ke media sosial Twitter, dan berhasil menemukan akun-akun media sosial terpercaya yang mencuitkan kabar pengeroyokan Ratna Sarumpaet, mulai dari Fadli Zon, Ferdinand Hutahean, juga Hanum Rais. Sebagai proses awal, mereka pun langsung 'menangkap' cuitan tersebut dan dibuat menjadi berita dengan konteks 'diduga' dan 'dikabarkan' untuk mengejar kecepatan publikasi.

Sementara Detik.com melakukan verifikasi setelah Fajar Pratama selaku redaktur pelaksana pertama mengetahui kabar Ratna Sarumpaet dipukuli usai melihat berita dari salah satu media daring. Namun berita di media tersebut tidak mencantumkan kutipan narasumber. Redaksi Detik.com pun pada akhirnya mengecek ke Ratna Sarumpaet via telepon. Akan tetapi saat dikonfirmasi apakah yang menjawab telepon itu Ratna atau bukan, orang tersebut langsung menutup teleponnya. Setelah itu, dikeluarkanlah tiga berita awal tentang dugaan pemukulan yang menimpa Ratna dengan mengambil kutipan narasumber dari cuitan media sosial. Alasan utama mengapa berita tersebut dipublikasikan, adalah karena cuitan di media sosial tersebut sudah dianggap kredibel dengan melihat terverifikasinya akun-akun narasumber tersebut (Pratama, Wawancara. 26 Oktober 2019).

Walaupun menggunakan kutipan media sosial, Tribunnews.com dan Detik.com mengaku sudah melakukan verifikasi terhadap sumber berita dari media sosial. Caranya adalah, dengan melakukan crosscheck apakah akun media sosial yang menyampaikan kabar pemukulan Ratna Sarumpaet sudah terverifikasi atau belum. Jika ternyata akun media sosial tersebut sudah terverifikasi maka Tribunnews.com dan Detik.com akan percaya dengan akun tersebut. Namun, apabila suatu kabar diinformasikan dari akun media sosial yang belum terverifikasi, Tribunnews.com dan Detik.com akan menghubungi tokoh yang bersangkutan atau melakukan $\mathrm{DM}$ via instagram.

Namun, perihal 'verifikasi yang diklaim telah dilakukan oleh Tribunnews.com dan Detik. com dibantah oleh anggota Dewan Pers Ahmad Djauhar, yang menganggap bahwa mencari tahu keaslian akun media sosial belum termasuk sebagai sebuah teknik verifikasi. Dalam upaya verifikasi, faktanya harus diketahui benar. Sementara apa yang diberitakan Tribunnews.com dan Detik.com ternyata salah.

Kalau hanya memverifikasi kebenaran akun, pemilik akun, dan sebagainya itu belum dianggap benar verifikasi. Verifikasi itu faktanya harus betul-betul benar. Fakta yang nyatanya setelah diberitakan ternyata salah. Nyatanya kan mereka tidak sepenuhnya melakukan verifikasi, hanya verifikasi yang memiliki akunnya itu bener atau ga, itu terlalu mudah kalau cek seperti itu. (Djauhar, Wawancara. 28 Februari 2020)

Situasi seperti ini sudah lama terjadi di dunia jurnalistik dunia, terutama di awal berkembangnya media sosial pada periode 2010-2011. Hermida mencatat, pers Amerika Serikat di tahun 2011 sangat terpengaruh dengan keberadaan media sosial saat itu, terutama Facebook dan Twitter. Walaupun disadari bahwa konten yang disebar sebuah akun sangat dipengaruhi oleh kesamaan pandangan orang-orang yang tergabung dalam jaringannya, namun kecepatan penyebaran informasinya menjadi sangat berguna bagi jurnalis untuk segera mendapatkan fakta dari berbagai lokasi, terutama dalam pemberitaan krisis atau bencana (Hermida, 2012).

Namun Hermida juga menyoroti masalah verifikasi fakta. Mengutip Bill Kovach dan 
168 | Kajian Jurnalisme

Volume 05 Nomor 02 Tahun 2022

DOI: $10.24198 / \mathrm{jkj} . v 5 \mathrm{i} 2.31701$

Tom Rosenstiel, Hermida menggarisbawahi bahwa disiplin verifikasi adalah fungsi klasik dari jurnalistik untuk mampu menyediakan fakta yang terjamin kebenarannya, jauh sebelum kemunculan media sosial. Ia menyatakan,

The rise of social media as a source for breaking news, and the speed at which information is disseminated on the network, poses a challenge to journalism's discipline of verification. Verification is at the core of the journalist's contention to objectively parse reality and claim a special kind of authority and status. (Hermida, 2012)

Untuk lebih jelasnya bagaimana seharusnya media melakukan verifikasi atas informasi yang berkembang di media sosial, Bill Kovach dan Tom Rosenstiel menawarkan lima konsep lain dalam melakukan produksi berita yang terverifikasi kebenarannya, yaitu: 1) Jangan menambah atau mengarang apa pun; 2) Jangan menipu atau menyesatkan pembaca, pemirsa, maupun pendengar; 3) Bersikaplah setransparan dan sejujur mungkin tentang metode dan motivasi Anda dalam melakukan reportase; 4) Bersandarlah terutama pada reportase Anda sendiri; dan 5) Bersikaplah rendah hati (Kovach dan Rosenstiel, 2014). Selain lima konsep tersebut, Brandtzæg dan kolega penelitinya menawarkan lima kategori yang perlu didapatkan, yaitu: 1) Trusted sources; 2) Access to eyewitnesses and authenticating sources; 3) Traditional journalistic methods (termasuk mencari teks, foto, video, dan pernyataan langsung dari narasumber melalui telepon atau e-mail); 4) Multimodal verification and verification tools; dan 5) Workaround methods atau menyatakan dengan tegas bahwa informasi berasal dari sumber yang belum terverifikasi saat sumber informasi memang sulit untuk didekati atau diketahui secara pasti (Brandtzaeg et al., 2015). Praktik-praktik seperti mencari saksi-saksi peristiwa, membuka sebanyak mungkin sumber berita, dan meminta komentar dari banyak pihak, tak lain adalah disiplin verifikasi. Disiplin verifikasi berfokus untuk menceritakan apa yang sebenarnya terjadi (Nursatyo, 2017).

Dari hasil penelitian, diketahui bahwa verifikasi yang dilakukan Tribunnews.com dan Detik.com belum sepenuhnya memenuhi kategori verifikasi Kovach dan Rosenstiel maupun Brandtzæg dkk. Yang dilakukan oleh kedua media tersebut baru sebatas mengetahui keaslian akun media sosial dan kredibilitas narasumber saja, belum pada verifikasi kebenaran informasi. Namun dalam pemberitaan awal, kedua media tersebut seakan-akan telah menyatakan kebenaran fakta penganiayaan, bukan dalam konteks dugaan.

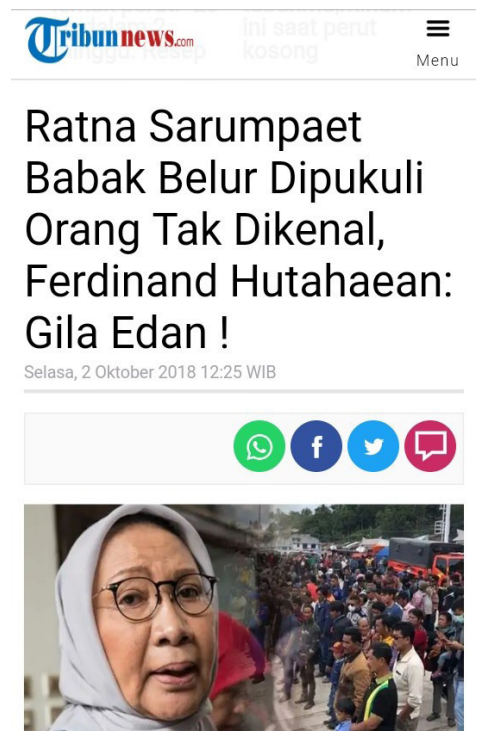

Gambar 3. Berita yang membenarkan peristiwa pemukulan Ratna Sarumpaet

Sumber: Tribunnews.com 
Pada contoh di Gambar 3, terlihat judul yang muncul sudah merupakan pernyataan bahwa insiden tersebut sudah merupakan fakta yang terjadi. Tidak terdapat kata 'diduga' atau 'dikabarkan' di situ. Padahal setelah ditelusuri, judul berita awal yang dipublikasikan TribunnewsBogor.com menggunakan kata 'dikabarkan'.

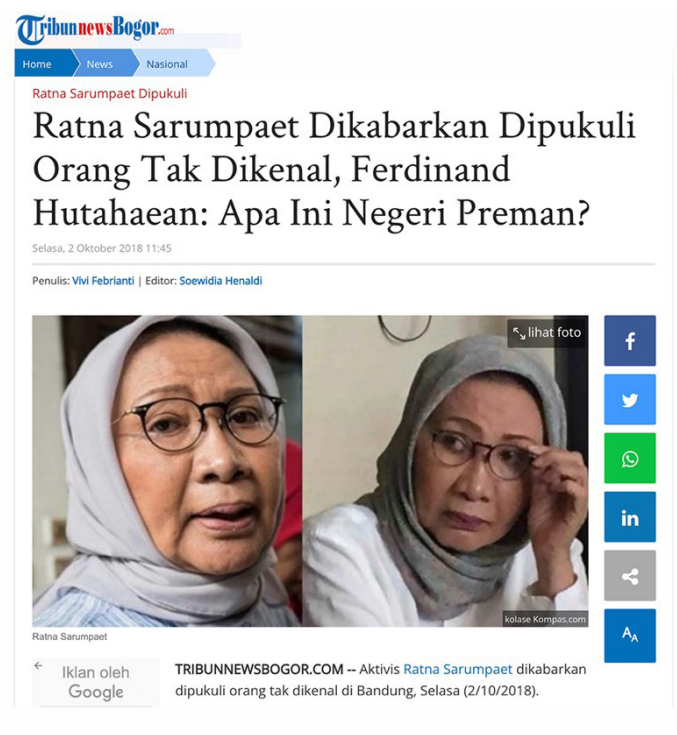

Gambar 4. Berita dugaan pemukulan Ratna Sarumpaet Sumber: TribunnewsBogor.com

Sehubungan dengan judul tersebut, Tribunnews.com memiliki alasan tersendiri untuk melepaskan kata tersebut. Pertama adalah alasan strategi redaksi untuk menjual produk digital. Jika judulnya sama, maka google akan memunculkan berita yang dari Tribunnews.com, halaman awal bukan TribunnewsBogor.com.

Faktor kedua adalah masalah rentang waktu antara turunnya berita pertama di kanal Bogor dengan waktu rilis di Tribunnews.com. Berita yang bersumber dari Tribunnews Bogor naik pukul 11.45 WIB. Kurang dari satu jam kemudian, tepatnya pukul 12.25 WIB, berita tersebut dirujuk ke kanal Tribunnews.com dengan mengganti judul (termasuk menghilangkan kata 'dikabarkan). Hal tersebut dikarenakan, selama kurang-lebih satu jam tersebut terdapat perkembangan-perkembangan yang mengerucut pada Ratna Sarumpaet dipukuli.

Ada sekitar satu jam...ya satu jam kurang, ketika satu jam itu semua sudah rame...jauh lebih rame, sehingga kenapa di tribunnews tidak pakai kata dikabarkan, karena semua media online semua mengerucut pada konteks 'oh iya dia babak belur' 'oh iya dia dipukuli' karena semakin banyak orang yang memposting Ratna Sarumpaet dipukuli, si ini...si A...si B, termasuk Fadli Zon...segala macem, orang-orang mereka lah seperti itu. (Henaldi, Wawancara. 21 Agustus 2019).

Mengejar kecepatan pemberitaan memang lumrah untuk media daring karena adanya salah satu karakteristik jurnalistik daring, Immediacy, yaitu kesegaran atau kecepatan penyampaian informasi. Akan tetapi mengejar kecepatan tidak bisa dijadikan alasan Tribunnews.com dan Detik.com untuk melewatkan verifikasi, karena meski media massa online dituntut cepat untuk mengejar aktualitas, termasuk memperbarui berita, mereka seharusnya tidak boleh mengabaikan check and recheck dan wajib meliput dari banyak sisi.

Verifikasi juga syarat terpenting untuk memberikan bobot tekan pemberitaan yang bernilai kemaslahatan (Machmud, 2016). Selain itu, penghilangan kata 'diduga' atau 'dikabarkan' pada berita yang belum jelas kebenarannya akan menyesatkan pembaca, dan membuat mereka 
170 | Kajian Jurnalisme

Volume 05 Nomor 02 Tahun 2022

DOI: $10.24198 / \mathrm{jkj} . v 5 \mathrm{i} 2.31701$

percaya bahwa Ratna Sarumpaet benar dipukuli. Hal ini tidak sesuai dengan salah satu dari lima konsep landasan disiplin verifikasi menurut Bill Kovach dan Tom Rosenstiel, yaitu: jangan menipu. Jangan menipu berarti jangan pernah menyesatkan khalayak. Membodohi orang adalah sebentuk kebohongan dan menghina ide bahwa jurnalisme harus berpegang teguh pada kejujuran (Kovach \& Rosenstiel, 2014).

Tidak hanya membuat judul yang membenarkan peristiwa penganiayaan terhadap Ratna Sarumpaet, Tribunnews.com dan Detik.com juga tidak melakukan permintaan maaf juga tidak melakukan ralat terhadap berita sebelumnya yang terbukti salah karena membenarkan kejadian yang belum terbukti kebenarannya. Padahal dalam kode etik jurnalistik pasal 10, dijelaskan wartawan Indonesia segera mencabut, meralat, dan memperbaiki berita yang keliru dan tidak akurat disertai dengan permintaan maaf kepada pembaca, pendengar, dan atau pemirsa $(\mathrm{CH} \&$ Suyanto, 2016).

Yulis berdalih, pihak Tribunnews.com tidak perlu melakukan hak ralat, dan menggunakan keterangan polisi sebagai hak jawab, atau permintaan maaf, karena mereka tidak mengubah fakta yang disampaikan narasumber.

Hak jawabnya dari polisi itu. Karena kita nggak merasa salah. Beda dengan kalau kita sengaja menulis bahwa Ratna Sarumpaet kita tahu dia dioperasi plastik tapi kita tulis dipukulin itu namanya kita berbohong. Ini kita nggak berbohong, tapi kita mendapat informasi dan kita konfirmasi fakta yang ada bahwa dia Ratna Sarumpaet dikatakan orang sekelilingnya adalah dipukuli. Makanya saya bilang media tidak berbohong, media dibohongi. Yang kita lakukan bukan minta maaf, yang kita lakukan meluruskan informasi yang ada, menjernihkan bahwa oh ternyata seperti ini fakta yang terjadi. (Sulistiawan, Wawancara. 21 Agustus 2019)

Melihat fenomena tersebut, Ahmad Dajuhar menjelaskan Tribunnews.com dan Detik. com seharusnya tetap melakukan ralat terhadap berita yang salah, karena menurut Ahmad, berita tersebut bisa berdampak menipu pembaca.

Kewajiban meralat informasi itu sudah diatur di kode etik jurnalistik, kalau memang salah suatu media harus berani meralat beritanya, dan dia harus meminta maaf pada pembacanya "bahwa berita yang kami turunkan kemarin ternyata tidak tepat" harus membuat disclaimer seperti itu kalau dia gentleman. Sangat disayangkan, padahal pembaca sudah jelas-jelas tertipu oleh fenomena itu. (Djauhar, Wawancara. 28 Februari 2020)

Hal kedua yang dipertanyakan dalam studi ini adalah bagaimana media memperlakukan sumber informasi sebagai narasumber pertama. Tribunnews.com menjelaskan, saat mendapat suatu informasi dari suatu sumber, yaitu dari media sosial, mereka tetap mengutamakan verifikasi dengan cara melihat keaslian akun media sosial narasumber. Baru setelah itu redaksi akan menaikkan berita sebagai publikasi yang mengejar kecepatan tadi. Hal tersebut dilakukan karena redaksi Tribunnews.com akan percaya dengan setiap akun yang sudah terverifikasi. Barulah setelah menyebarkan berita awal berisi kutipan dari akun media sosial narasumber, redaksi akan 'menerjunkan' tim lapangan untuk melakukan konfirmasi dan mengecek terkait informasi yang beredar.

Perlakuan serupa terhadap sumber informasi yang beredar di media sosial juga terlihat di Detik.com. Wartawan Detik.com juga menganggap akun-akun media sosial yang sudah terverifikasi adalah akun asli yang bisa dipercaya, termasuk dalam pembuatan pemberitaan dugaan pemukulan Ratna Sarumpaet.

Perlakuan berbeda baru akan dilakukan Tribunnews.com, jika ingin mengambil sumber informasi seperti kutipan narasumber atau kabar peristiwa dari media sosial, yang berasal dari akun yang belum terverifikasi. Terdapat tiga cara yang bisa dilakukan tim media sosial Tribunnews.com. Pertama, wartawan bisa melakukan direct messages (DM) terhadap orang 
tersebut untuk memastikan informasi yang disampaikan akun tersebut adalah asli cuitan pemiliknya. Kedua, tim redaksi akan mengecek setiap postingan akun tersebut untuk mengetahui dengan siapa dia berbalas pesan. Ketiga, tim media sosial akan mengecek pesan yang diposting di akun tersebut, misalnya jika yang disebar akun tersebut berupa video, maka tim media sosial akan memanfaatkan tools dari Google untuk melakukan verifikasi.

Di pihak Detik.com, redaksi baru akan melakukan verifikasi ketat terhadap sumber informasi di media sosial apabila akun tersebut bukan milik narasumber-narasumber yang sudah diketahui oleh Detik.com. Mereka akan melakukan verifikasi ketat dengan cara menghubungi ke instansi yang terkait dengan informasi yang beredar di media sosial.

Fenomena mengejar kecepatan dengan menggunakan konten media sosial memang telah menjadi hal yang biasa terjadi sejak dulu. Hermida mengakui, media-media massa besar di Amerika Serikat, Inggris, atau Australia juga melakukan hal yang sama.

Mainstream media coherently used social media tools to cover a major event for the first time during the G20 summit in London in April 2009. Journalists from leading news organizations such as the BBC and the Guardian provided regular updates from the streets of London as events unfolded. According to BBC News website editor Steve Herrmann, this approach to reporting "allowed us to build a nuanced, full picture of the protests in real-time on a map" (Hermida, 2012).

Kendati demikian, media massa mainstream tersebut tetap berusaha menjaga agar fakta yang dipublikasikan tetap memenuhi kaidah jurnalistik. Mereka tetap melakukan proses jurnalistik tradisional dan memperlakukan kegiatan di media sosial sebagai suplemen pemberitaan di platform utama mereka (Hermida, 2012).

Senada dengan Hermida, Ahmad Djauhar dari Dewan Pers menyatakan informasi media sosial adalah bahan mentah yang harus diproses lebih dulu untuk mencari tahu kebenarannya. Ia tidak sepakat dengan verifikasi media sosial yang berhenti pada pengecekan kebenaran pemilik akun dan bukan pada informasinya.

Nggak bisa mentah-mentah dari medsos diambil kemudian disajikan lah terus ngapain harus punya media kalau gitu caranya. Kenapa nggak orang dikasih link aja ini lho peristiwanya lihat sendiri di facebook atau di twitter, lah kalo gitu bukan pekerjaan wartawan. Pekerjaan wartawan itu disiplin verifikasi, data itu juga perlu diperhatikan. (Djauhar, Wawancara. 28 Februari 2020).

Terkait dengan berita yang membenarkan kabar pemukulan Ratna Sarumpaet, Detik.com merasa tidak ditipu.

Kita nggak ketipu karena dari awal kita skeptis ... kita pakai kata 'diduga' 'dikabarkan' atau mengklaim kalau kita belum bisa memastikan 100\% kebenarannya ... Pemberitaan Ratna Sarumpaet ini justru mengingatkan kita supaya mempertahankan prinsip verifikasi seperti ini. Kita jangan mudah percaya klaim atas aparat keamanan, klaim masyarakat, klaim netizen apalagi sekarang medsos isinya riuh. (Damarjati, Wawancara. 26 Agustus 2019).

Lain halnya dengan dengan Tribunnews.com yang tidak merasa bersalah dengan tidak menggunakan kata 'diduga' atau 'dikabarkan', karena tidak mengubah fakta yang disampaikan narasumber, juga tidak menipu masyarakat dengan beritanya. Justru Tribunnews.com yang telah ditipu oleh Ratna Sarumpaet dan teman-temannya yang menjadi narasumber pemberitaan (Sulistiawan, Wawancara. 26 Agustus 2019).

Dalam hal ini, terlihat bahwa kedua media daring Indonesia ini belum melakukan disiplin verifikasi sepenuhnya, seperti yang dianjurkan oleh Kovach dan Rosenstiel maupun Brandtzæg dan koleganya. Berdasarkan kedua konsep tersebut, baik Tribunnews.com maupun Detik. com sudah memenuhi setidaknya konsep kejujuran tanpa merubah fakta. Seorang wartawan memang harus jujur dalam menyampaikan informasi yang dia dapat, dan tidak boleh mengubah 
172 | Kajian Jurnalisme

Volume 05 Nomor 02 Tahun 2022

DOI: $10.24198 / \mathrm{jkj} . v 5 \mathrm{i} 2.31701$

informasi tersebut, karena salah satu etika personal wartawan adalah kejujuran (fairness), yang berarti dalam pekerjaannya seorang penulis harus jujur dalam mencari, mengumpulkan, dan mengelola informasi, serta jujur mengungkapkan apa yang diungkapkan di tulisannya (Diaz \& Sufyan, 2020).

Namun, kejujuran dengan cara tidak mengubah fakta dari narasumber tidak cukup menjadi pembenaran dari wartawan Tribunnews.com atau Detik.com untuk terlalu percaya dengan setiap pendapat narasumber yang telah dikenal. Wartawan perlu mengedepankan akurasi. Akurat berarti informasinya jelas, dan tidak menyulut kontroversi di masyarakat. Selain standar operasional dan profesional, akurasi juga menjadi standar etik bagi wartawan (Halik, 2020). Dalam hal ini, kedua media massa tidak memenuhi konsep kedua dan keempat dari Kovach dan Rosenstiel, yang senada dengan kategori kedua dari Brandtzæg tentang mengakses saksi mata dan sumber otentik. Hal tersebut terjadi karena kedua media terlampau percaya dengan akun media sosial yang sudah dikenal.

Konsep kelima dari Bill Kovach dan Tom Rosenstiel tentang kerendahhatian juga harus menjadi perhatian, terutama di saat kedua media bersekukuh tidak melakukan kesalahan atau bahkan menyalahkan pihak narasumber yang melakukan penipuan terhadap mereka. Bagaimanapun itu adalah tugas dari media massa untuk memeriksa kebenaran sebelum memublikasikan sebuah berita. Kehadiran media sosial memang memberi kemudahan untuk wartawan mencari sebuah informasi, namun di saat yang bersamaan, mereka juga ditantang untuk bisa membuktikan kebenaran sumber atau kredibilitas dalam proses verififikasi (Sumadiria, 2011).

Hal ketiga yang dipertanyakan dalam studi ini adalah mengenai pertanggungjawaban Tribunnews.com dan Detik.com terhadap reliabilitas informasi di media sosial. Hal ini berkaitan dengan jumlah laporan masyarakat berkaitan dengan keluhan yang disebabkan konten media sosial yang merugikan.

Dalam data yang disampaikan Sahrul Mauludi, didapat fakta tingginya angka pengguna media sosial di Indonesia (yaitu sekitar 106 juta pengguna aktif) diikuti dengan tingginya jumlah laporan polisi terkait dengan pelanggaran atas UU No. 11 Tahun 2008 tentang informasi dan Transaksi Elektronik (UU ITE). South East Asia Freedom of Expression Network (SAFENet) pada tahun 2014 mencatat hanya 20 laporan. Angka tersebut meningkat setahun berikutnya (2015) menjadi 35, dan kembali meningkat tahun 2016 dengan 177 laporan, di mana laporan yang berkaitan dengan pasal 27 Ayat (3) UU ITE tentang pencemaran nama baik menempati urutan pertama dengan jumlah 141 (Mauludi, 2018).

Dalam mempertanggungjawabkan reliabilitas, bisa dikatakan Tribunnews.com dan Detik. com sebenarnya sudah cukup baik dalam menjalankan verifikasi dan konfirmasi terhadap setiap informasi yang beredar di media sosial. Keduanya tidak asal mengambil informasi (cuitan), konten video, atau foto di media sosial tanpa mencari tahu kebenarannya. Masing-masing media memiliki cara dalam meluruskan informasi dan mengungkap kebenaran dari kabar di media sosial. Tribunnews.com dengan kerja teliti tim media sosialnya, serta Detik.com dengan sikap wartawannya yang tetap mengutamakan keterangan dari pihak berwajib.

Selain membentuk tim media sosial untuk mempertanggungjawabkan kabar dari media sosial, Tribunnews.com juga mempunyai standar prosedur, yaitu saat akun media sosial yang menyampaikan suatu kabar sudah terverifikasi, Tribunnews.com akan percaya bahwa apapun yang dicuitkan narasumber, maka narasumber tersebut akan bertanggungjawab penuh dengan cuitannya.

Sementara itu, Detik.com juga berpendapat sama terkait alasan percaya kepada narasumber yang mencuitkan di media sosial. Hanya saja terdapat sedikit perbedaan berkaitan 
dengan berita dugaan penganiayaan Ratna Sarumpaet. Danu Damarjati, reporter Detik.com, menyebut wartawan tetap diminta oleh redaksi untuk melakukan konfirmasi kepada narasumber. Semua wartawan Detik.com memang dikatakan Danu memiliki kontak-kontak narasumber dari berbagai kalangan mulai dari atlit hingga politikus, dan setiap kanal memiliki kontak narasumber-narasumber yang berkaitan dengan kanal mereka bekerja. Setiap wartawan juga bisa saling meminta kontak narasumber dari kanal yang berbeda jika dibutuhkan (Damarjati, Wawancara. 26 Agustus 2019).

Sayangnya, pada kasus pemberitaan dugaan penganiayaan Ratna Sarumpaet ini, meskipun wartawan Tribunnews.com dan Detik.com sudah cukup baik dalam menangani kabar yang beredar di media sosial dengan melakukan verifikasi terhadap akun-akun media sosial yang berkaitan, eksekusinya kurang tepat karena kedua media massa tersebut terlalu menganggap kabar dugaan pemukulan ini mendesak dan harus cepat diketahui publik. Keterangan dari pihak aparat yang menangani kasus tersebut dianggap dapat diberitakan di lain waktu.

Keberadaan media sosial yang membuat informasi dapat menyebar secara tidak terkendali membuat warga memerlukan wartawan untuk mencari kebenaran informasi yang lengkap dan mendalam. Bill Kovach dan Tom Rosenstiel menyebutkan bahwa warga memiliki hak akan pengetahuan yang mendalam dan terbaru tentang isu-isu dan tren penting pada saat proliferasi informasi dan sumber semakin meningkat tidak terkendali (Kovach \& Rosenstiel, 2014). Jurnalisme harus loyal kepada warga apapun yang terjadi, karena warga adalah 'tuan' bagi jurnalisme. Setiap informasi yang disajikan jurnalisme idealnya bertujuan untuk kebaikan dan pencerahan warga (Eddyono, HT, \& Irawanto, 2019).

Seiring dengan meningkatnya sumber informasi, wartawan tidak boleh dimanjakan oleh informasi-informasi yang menegaskan pandangan mereka sendiri, melainkan harus juga mencari informasi kritis, serta tanggung jawab untuk fokus pada apa hal yang penting (Kovach \& Rosenstiel, 2014). Dalam hal ini, yang dilakukan wartawan Tribunnews.com dan Detik.com justru berlawanan dengan prinsip tersebut. Mereka lebih berfokus pada membuat publik tahu dengan cepat berita bahwa Ratna Sarumpaet dipukuli, bukan kepentingan untuk mengungkapkan kebenaran kasus agar warga mendapat informasi yang sesuai fakta. Jadi saat mereka mengaku membuat berita karena penting untuk publik, justru keduanya malah tidak bekerja untuk memberikan informasi atau kebenaran kepada publik. Padahal, loyalitas pertama jurnalisme adalah kepada warga/masyarakat. Kesetiaan kepada masyarakat adalah salah satu unsur terpenting, dan keberpihakan dari berita pemberitaan haruslah bagi kepentingan masyarakat umum (Fadil \& Yudhapramesti, 2019).

Melihat fenomena pemberitaan kasus hoaks Ratna Sarumpaet di Tribunnews.com dan Detik.com, Ahmad Djauhar menyimpulkan bahwa kedua media daring tersebut tidak melakukan disiplin jurnalisme dengan sempurna dalam memberitakan awal berita kasus hoaks Ratna Sarumpaet. Mereka melakukan kecerobohan newsroom dengan membenarkan persitiwa pemukulan terhadap Ratna Sarumpaet saat kebenaran kasusnya belum terungkap, tidak membuat hak ralat pada berita-berita yang salah dan membohongi pembaca, dan hanya mengambil postingan media sosial narasumber sebagai kutipan berita, sementara seharusnya informasi tersebut diverifikasi untuk menemukan fakta yang sebenar-benarnya (Djauhar, Wawancara. 28 Februari 2020).

\section{SIMPULAN}

Dari hasil studi di atas, dapat disimpulkan tiga hal berkaitan dengan pertanyaan penelitian. Pertama, Tribunnews.com dan Detik.com pada berita dugaan penganiayaan Ratna Sarumpaet belum melakukan verifikasi kebenaran informasinya, sehingga mereka salah 
174 | Kajian Jurnalisme

Volume 05 Nomor 02 Tahun 2022

DOI: $10.24198 / \mathrm{jkj} . v 5 \mathrm{i} 2.31701$

dengan membenarkan informasi penganiayaan terhadap Ratna Sarumpaet yang faktanya belum terbukti. Hal tersebut tidak sesuai dengan konsep verifikasi informasi yang dianjurkan Kovach dan Rosenstiel maupun Brandtzæg, terutama dalam hal mengakses sumber otentik. Kedua, dari cara kedua media memperlakukan sumber informasi dari media sosial, Tribunnews.com dan Detik.com belum dapat dikatakan verifikasi informasi yang sempurna, karena berdasarkan beberapa konsep yang ada, proses verifikasi memerlukan komponen-komponen yang lebih lengkap dan teliti. Terakhir, dalam hal mempertanggungjawabkan reliabilitas di media sosial, Tribunnews.com dan Detik.com belum melakukannya secara sempurna pada berita-berita awal mereka. Walaupun pada berita-berita selanjutnya ada upaya verifikasi, namun isinya tidak tegas dan mendalam karena mereka hanya menggolongkan klaim peristiwa tersebut sebagai dugaan.

Berdasarkan temuan dalam studi ini, penulis menyarankan agar wartawan media daring, terutama Tribunnews.com dan Detik.com, lebih memperdalam konsep verifikasi dalam studi jurnalistik, selain juga mengenai kode etik dan juga PPMS sebagai pedoman melakukan pemberitaan di tengah maraknya informasi di media sosial. Dalam penelitian ini, penulis tidak menemukan bahwa wartawan kedua media telah memaknai verifikasi secara teoretis dan peraturan jurnalisme seperti KEJ mau pun PPMS dengan benar. Selain itu, penulis menyarankan Dewan Pers untuk lebih tegas mendukung pihak berwenang untuk menegakkan hukum terhadap penyebaran berita hoaks, karena dalam studi ini belum ditemukan alasan mengapa wartawan/media yang membuat berita salah dengan menggunakan kutipan dari media sosial tidak mendapat hukuman, padahal Dewan Pers mengatakan tindakan tersebut tidak benar. Terakhir, penulis menyarankan agar ada upaya meningkatkan sosialisasi ke media-media massa di Indonesia bahwa sumber informasi dari media sosial bukan untuk disajikan mentah-mentah, mengingat masih banyak insiden yang berkaitan dengan informasi media massa yang tidak akurat bersumber dari media sosial. Diharapkan di masa datang tak ada lagi wartawan yang membuat berita dengan hanya mengutip media sosial tanpa verifikasi mendalam.

\section{DAFTAR PUSTAKA}

Batubara, H. (2019). Ahmad Dhani ditahan, Fahri Hamzah : elektabilitas Jokowi bakal turun. Diakses dari detiknews website: https://news.detik.com/berita/d-4404302/ahmad-dhaniditahan-fahri-hamzah-elektabilitas-jokowi-bakal-turun

Brandtzaeg, P. B., Lüders, M., Spangenberg, J., Rath-Wiggins, L., \& Følstad, A. (2015). Emerging journalistic verification practices concerning social media. Journalism Practice, 10(3), 323-342. https://doi.org/10.1080/17512786.2015.1020331

CH, P., \& Suyanto. (2016). Implementasi kode etik jurnalistik pada berita kriminal (berita pembunuhan) di surat kabar Pekanbaru MX. JOM FISIP, 3(1), 1-16. Diakses dari https:// jom.unri.ac.id/index.php/JOMFSIP/article/view/8630

Diaz, J., \& Sufyan, A. M. (2020). Analisis kerja jurnalistik di media massa Tribunnews.com pada pemberitaan kasus \#JusticeForAudrey. E-Proceeding of Management, 7(2), 42654276. Diakses dari https://openlibrarypublications.telkomuniversity.ac.id/index.php/ management/article/view/13547

Eddyono, S. A., HT, F., \& Irawanto, B. (2019). Menyoroti jurnalisme warga: Lintasan sejarah, konflik kepentingan, dan keterkaitannya dengan jurnalisme profesional. Jurnal Kajian Jurnalisme, 3(1), 1-17. https://doi.org/10.24198/jkj.v3i1.21762

Fadil, R. M., \& Yudhapramesti, P. (2019). Wacana Islam radikal dalam majalah Tempo. Jurnal Kajian Jurnalisme, 3(1), 57-75. https://doi.org/10.24198/jkj.v3i1

Halik, A. (2020). Atmosfer kebebasan pers. Jurnalisa, 6(1), 140-159. https://doi.org/10.24252/ jurnalisa.v6i1.13667 
Volume 05 Nomor 02 Tahun 2022

DOI: $10.24198 / j k j . v 5 i 2.31701$

Hermida, A. (2012). Social journalism: Exploring how social media is shaping journalism. In E. Siapera \& A. Veglis (Eds.), The Handbook of Global Online Journalism (pp. 309328). New York: John Wiley \& Sons, Inc.

Hidayat, D., \& Anisti. (2015). Wartawan media Now dalam mengemas berita: Perspektif situation theory. Jurnal ASPIKOM, 2(5), 295-303. https://doi.org/10.24329/aspikom. $\mathrm{v} 2 \mathrm{i} 5.81$

Juditha, C. (2013). Akurasi berita dalam jurnalisme online (Kasus dugaan korupsi Mahkamah Konstitusi di portal berita Detiknews). Jurnal Pekommas, 16(3), 145-154. https://doi. org/10.30818/jpkm.2013.1160301

Khalid, I. (2019). Kredibilitas media cetak dan media online. At-Tadabbur: Jurnal Penelitian Sosial Keagamaan, 9(1), 84-105. Diakses dari http://www.ejournal.an-nadwah.ac.id/ index.php/Attadabbur/article/view/85

Khotimah, C. S., \& Nuraeni, R. (2019). Analisis framing pemberitaan hoaks penganiayaan Ratna Sarumpaet di media online Tribunnews.com dan Detik.com periode 03 - 05 Oktober 2018. E-Proceeding of Management, 6(2), 4646-4656. Diakses dari https:// openlibrarypublications.telkomuniversity.ac.id/index.php/management/article/ view/10485

Kovach, B., \& Rosenstiel, T. (2014). The elements of journalism: What newspeople should know and the public should expect. New York: Three Rivers Press.

Loraine, B., Wick, W., \& Gumbinger, C. (2020). How to use and assess qualitative research methodes. Neurogical Research and Practice, 2(14), 1-10. https://doi.org/10.1186/ s42466-020-00059-z

Machmud, A. (2016). Mengartikulasikan "Trial by the press" dalam kemasan pemberitaan media yang berorientasi kemaslahatan. Masalah - Masalah Hukum, 45(1), 41-48. https:// doi.org/10.14710/mmh.45.1.2016.41-48

Mauludi, S. (2018). Seri cerdas hukum: Awas hoax! cerdas menghadapi pencemaran nama baik, ujaran kebencian dan hoax. Jakarta: Elex Media Komputindo.

Nasionalita, K., \& Nugroho, C. (2020). Media agenda on Yogyakarta Sultanate Succession. Jurnal Kajian Jurnalisme, 4(1), 61-74. https://doi.org/10.24198/jkj.v4i1.24071

Nur, C., \& Wardiana, D. (2018). Manajemen strategi redaksi dan bisnis koran olahraga Topskor dalam menghadapi persaingan dengan media online di era konvergensi media. Jurnal Kajian Jurnalisme, 1(2), 124-146. https://doi.org/10.24198/jkj.v3i2

Nursatyo. (2017). Dominasi ideologi media dalam proses produksi beritakasus Ahmadiyah Cikeusik tahun 2011 di majalah Tempo. Jurnal Ilmu Dan Budaya, 40(56), 6511-6538. Diakses dari http://journal.unas.ac.id/ilmu-budaya/article/view/420

Paramastri, N. A., \& Gumilar, G. (2019). Penggunaan Twitter sebagai medium distribusi berita dan news gathering oleh Tirto.Id. Jurnal Kajian Jurnalisme, 3(1), 18-38. https://doi. org/10.24198/jkj.v3i1.22450

Sumadiria, H. (2011). Jurnalistik Indonesia: Menulis berita dan feature panduan praktis jurnalis profesional. Bandung: Remaja Rosda Karya.

Triadi, R. B., \& Aziz, F. (2019). Konstruksi media pada politikus wanita: Judul pemberitaan kasus hoaks tokoh politik perempuan di media massa online Indonesia. Deiksis, 11(02), 140-150. https://doi.org/10.30998/deiksis.v11i02.3636

Umar, R. (2019). Fadli Zon pertanyakan nawacita Presiden Jokowi saat menjadi capres tahun 2014. Diakses dari TribunManado.co.id website: https://manado.tribunnews. com/2019/01/28/fadli-zon-pertanyakan-nawacita-presiden-jokowi-saat-menjadi-caprestahun-2014 
176 | Kajian Jurnalisme

Volume 05 Nomor 02 Tahun 2022

DOI: $10.24198 / \mathrm{jkj} . v 5 \mathrm{i} 2.31701$

Winora, R., Hidayat Rahmat, D., \& Besman, A. (2021). Penerapan Kode Etik Jurnalistik dalam penulisan berita kriminal pada media online Infobekasi.co.id. Jurnal Kajian Jurnalisme, 4(2), 166-176. https://doi.org/10.24198/jkj.v4i2.29323

Wintterlin, F. (2020). Trust in distant sources: An analytical model capturing antecedents of risk and trustworthiness as perceived by journalists. Journalism, 21(1), 130-145. https:// doi.org/10.1177/1464884917716000

Yin, R. K. (2014). Studi kasus: Desain dan metode. Jakarta: Raja Grafindo Persada. 